IIIIIIIIIIIIIII!IIIIIIIII!

論 文

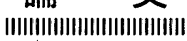

\title{
糸のヤング率がつば付ボビンの変形に及ぼす影響
}

$\begin{array}{lllll}\text { 金沢大学工学部 } & \text { 新 } & \text { 宅 } & \text { 救 } & \text { 徳 (会員) } \\ \text { 金沢大学工学部 } & \text { 喜 } & \text { 成 } & \text { 年 } & \text { 泰 (会員) } \\ \text { 金沢大学工学部 } & \text { 堀 } & & \text { 純 } & \text { 也 (会員) }\end{array}$

\section{Effect of Yarn Modulus on Deformation of Flanged Bobbin}

\author{
Sukenori Shintaku, Toshiyasu Kinari and Junnya Hori
}

Faculty of Technology, Kanazawa University, Kodatsuno, Kanazawa

\begin{abstract}
Stress distribution in the yarn package wound on the flanged bobbin is made clear by using the data of model experiment on which yarn packages are formed by several kinds of yarn that has different Young's modulus. They are also useful for obtaining the deformation of the flanged bobbin using the finite element analysis. The following results are obtained.

(1) The smaller Young's modulus of the yarn, the larger the radial load compressing the barrel of the flanged bobbin. Increasing rate of the radial compressive stress decreases with accumulated yarn layer.

(2) The smaller Young's modulus of the yarn, the larger the axial load expanding the flanges of the bobbin. Increasing rate of the axial expanding load increases with cumulated yarn layer.

(3) The radial load compressing the barrel of bobbin is larger than the axial load expanding its flanges.

(4) The smaller Young's modulus of the yarn, the larger the flanged bobbin deforms by internal stess in yarn package. The maximum deformation is generated near the root of its flanges.
\end{abstract}

(Received October 1, 1993)

(Accepted for Publication January 10, 1994)

摘

要

目的 ヤング率の異なる糸を用いてつば付ボビン上に巻糸体を形成した際の巻糸体内部の応力分布状態をモデル実験を通し て求める: また，巻系体内部の応力によるつば付ボビンの変形について有限要素法により解析する.

成果 (1)糸層がつば付ボビンの芯筒を圧縮する荷重は糸のヤング率が小さいほど大きく，その荷重増加の割合は糸層の増加 に伴い小さくなる.

(2)系層がボビンのつばを圧縮する荷重は糸のヤング率が小さいほど大きく, その荷重増加の割合は系層の増加に伴い大きく なる。

(3)巻系体はボビンのつばよりも芯筒を強く圧縮する.

(4)巻糸体内部応力によるつば付ボビンの変形は, 糸のヤング率が小さいほど大きく, つばのつけ根付近での変位が最も大きく なる。

(平成 5 年 10 月 1 日受理)

(平成 6 年 1 月 10 日審査終了)

\section{1. 緒 言}

巻取工程において糸 1 本に加わる力は小さいもの の, 系層を幾層にあ累積していくことによって巻糸 体内部で重畳されていく力は非常に大きくなる：そ のため, 伸度の大きい系, 特にナイロン加工糸や高
弾性糸などを用いての糸のパッケージ形成時やたて 糸ビームへの巻き取り時にボビンやビームが変形・ 破損することがある.これらの現象は巻張力や巻量 を小さくすることによって問題発生を減らすことが できるが，ボビンやビームの設計強度という観点か ら考えると根本的な解決には至っていない。 
これまでにも巻糸体の内部状態についての理論解 析や実験 ${ }^{12)}$ は数多く報告され，巻系体芯筒あるい はビームフランジ等の強度設計に役立っている.こ れらの中で巻糸体の芯筒やフランジの受ける力を測 定した報告 ${ }^{3 \sim 8)}$ はあるが, ボビンやバレルの変形につ いて実際面から検討したものは見当たらない.

このため我々は, 巻糸体の内部ひずみについてモ デル実験によりその挙動を明らかにし ${ }^{13)}$, 巻系体内 部の円周方向応力が全域にわたって均一となるよう な巻糸体を形成してその張力制御による効果を検討 した ${ }^{14)}$. さらに, 巻系体の円周方向ヤング率から半 径方向ヤング率を推定する方法について検討し ${ }^{15)}$, 巻糸体の半径方向ヤング率分布を任意に設定できる 理論式を導き，実際の巻糸体を用いた実験により測 定された半径方向ヤング率分布を適用することによ ってより正確なひずみ解析を行ってきた ${ }^{16)}$.

本報ではフィラメント糸の撚糸製造工程で使用さ れるつば付ボビン（以後本報ではボビンと記す）の 変形に着目し，ヤング率の異なる系を用いて巻系体 を形成した際のボビンの変形についてモデル実験を 通して明らかにする. まず初めに，種々のヤング率 の系をつば付ボビンに張力を一定として巻き取り， 糸層累積に伴う巻系体内部応力によるボビンの芯筒 圧縮荷重およびつば圧縮荷重の変化を測定し, 系の ヤング率の違い（すなわち巻糸体の円周方向ヤング 率の違い）がボビンの圧縮力に及ぼす影響について 考察する.そして，この測定值と異方性を考慮した 巻系体内部応力理論より算出した値とを比較するこ とにより, 巻系体の半径方向ヤング率を推定し, 実 際に近い巻系体内部の応力分布状態を求める.さら に, 得られたボビンの圧縮応力を用いて有限要素法 によりボビンの変形について解析する.

なお，本報は巻糸体の形成が終了した時点でのボ ビンの状態について静力学的に解析を行うことを目 的とし, 巻系体の形成過程でのボビンの変形や経時 変化による糸の応力緩和現象については無視する.

\section{2. 巻糸層がボビンに及ぼす圧縮力に ついてのモデル実験}

\section{1 つば付ボビン上での糸層の形成}

合織フィラメント糸に撚りをかける工程ではイタ リー式撚系機またはダブルッイスタが用いられる. イタリー式撚系機は供給原糸のパッケージを回転さ せて糸に撚りを加えるアップッイスタの形式である

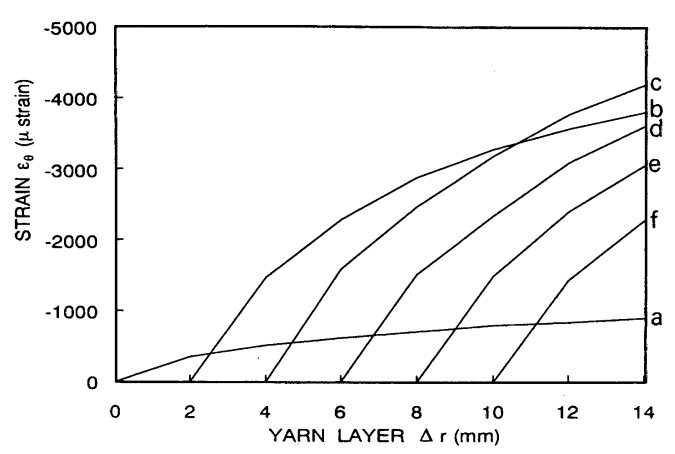

Fig. 1 Relation between the circumferential strain $\varepsilon_{\theta}$ and the cumulated yarn layer $\Delta r a, b, c, d$, $e$ and $f, \varepsilon_{\theta}$ measured by the gauge placed at $\Delta r=0 \mathrm{~mm}, 2 \mathrm{~mm}, 4 \mathrm{~mm}, 6 \mathrm{~mm}, 8 \mathrm{~mm}$ and 10 $\mathrm{mm}$, respectively

ため，小型のパッケージに巻き返すことが必要であ る. 織物表面の光沢を重視するフィラメント織物な どにおいては，このパッケージは系の接圧を利用す る RT ワインダによらず，ボビンワインダと称され るワインダ（後述の図 2 参照）により，つば付ボビ ン（後述の図 8 参照）上に形成される。ボビンワイ ンダではテンサにより一定張力に制御された糸が, 別駆動のトラバースガイドによってトラバースを与 えられながらボビン上に巻き取られる.

このように巻系体を形成した場合, 巻糸体内部の 円周方向ひずみ（詳しい実験方法は文献13）参照） は巻系体径増加に伴い, 図 1 に示すように増加して いく.図 1 はナイロンフィラメント糸 $70 \mathrm{D}$ 無撚糸 （実測によると $7.60 \mathrm{Tex}$ (68.4D)）を $17 \mathrm{gf}(0.167$ N) の一定張力で糸層厚さ $13.5 \mathrm{~mm}$ まで巻き取った 場合の一例である，糸層増加に伴うひずみは, 初め に巻かれた張力を保持しながらその上に糸層が累積 していくのであれば，直線的に増加するはずである が, 実験結果によれば初めは傾きが大きいが, 徐々 に鈍くなっている．これは内層側の糸層のひずみが それよりあ外側の糸層の締め付け力によって減少し ているためである.すなわち，糸層の半径方向にお けるひずみ分布は複雑に変化していることが分か る.このような複雑な張力状態を種々の糸種に対し て検討するため, 本報では以下に示すような単位面 積当たりの糸張力 $T$ を用いて整理する.

$$
T=(F \cdot t \cdot N) / S
$$

ここで $F$ は糸をボビンに巻き付けるときの張力, $t$ は糸層厚さが $13.5 \mathrm{~mm}$ になるまでに要する巻き取 時間, $N$ はボビンの回転数 $(2,000 \mathrm{rpm}$ で一定), $S$ 
Table1 Properties of the yarn used in experiments

\begin{tabular}{|c|c|c|c|c|}
\hline Yarn & $\begin{array}{c}\text { Twist } \\
\text { number }\end{array}$ & $\begin{array}{c}\text { Yarn } \\
\text { fineness }\end{array}$ & $\begin{array}{c}\text { Cross } \\
\text { sectional area }\end{array}$ & $\begin{array}{l}\text { Young's } \\
\text { modulus }\end{array}$ \\
\hline $\begin{array}{l}\text { Polyester } \\
\text { original yarn }\end{array}$ & as spun & $\begin{array}{ll}8.49 & \text { Tex } \\
(76.4 & \text { D) }\end{array}$ & $6.11 \times 10^{-3} \mathrm{~mm}^{2}$ & 12. $4 \mathrm{GPa}$ \\
\hline $\begin{array}{l}\text { Polyester } \\
\text { twisted yarn }\end{array}$ & $1500 \mathrm{~T} / \mathrm{m}$ & $\begin{array}{ll}8.91 & \text { Tex } \\
(80.2 & \text { D) }\end{array}$ & $6.41 \times 10^{-3} \mathrm{~mm}^{2}$ & $5.0 \mathrm{GPa}$ \\
\hline $\begin{array}{l}\text { Nylon } \\
\text { original yarn }\end{array}$ & as spun & $\begin{array}{ll}7.60 & \text { Tex } \\
(68.4 & \mathrm{D})\end{array}$ & $6.67 \times 10^{-3} \mathrm{~mm}^{2}$ & 2. $7 \mathrm{GPa}$ \\
\hline $\begin{array}{l}\text { Nylon } \\
\text { twisted yarn }\end{array}$ & $1500 \mathrm{~T} / \mathrm{m}$ & 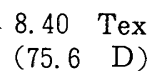 & $7.37 \times 10^{-3} \mathrm{~mm}^{2}$ & $0.51 \mathrm{GPa}$ \\
\hline
\end{tabular}

Table 2 Winding condition to form yarn package on flanged bobbin

\begin{tabular}{c|c|c|c}
\hline \hline Yarn & $F(\mathrm{mN} /$ yarn $)$ & $t(\mathrm{~min})$ & $T(\mathrm{MPa})$ \\
\hline Polyester original yarn & 176 & 90 & 19.6 \\
\hline Polyester twisted yarn & 225 & 70 & 19.5 \\
\hline Nylon original yarn & 167 & 95 & 19.5 \\
\hline Nylon twisted yarn & 206 & 76 & 19.3 \\
\hline
\end{tabular}

$F:$ Winding tension of a yarn

$t$ : Required time to form yarn package

$T$ : Tension per unit cross sectional area of yarn package

はボビンを回転軸方向に中央で切断したときの糸層 の断面積 $\left(120 \times 13.5 \mathrm{~mm}^{2}\right)$ である.これを表 1 に示 す 4 種類のヤング率 $E_{\theta}$ の異なる糸に対して $T$ が一 定值 $2 \mathrm{kgf} / \mathrm{mm}^{2}(19.6 \mathrm{MPa})$ となるように, 各糸種 に応じて $F$ を調節した. このときの $F$ と $t$ を表 $2 に$ 示す.なお表 1 中の各糸に対する $E_{\theta}$ はそれぞれの 糸が表 2 に示された $F$ の値になったとき（すなわち $T$ が $2 \mathrm{kgf} / \mathrm{mm}^{2}$ (19.6MPa) となったとき) のひず みに対する応力 (糸の単位断面積当たりの) の割合 である.

\section{2 実験方法}

巻糸体形成時のボビンにかかる荷重を測定するた めの実験装置の概略を図 2 に示す. 装置はつば付ボ ビンの代わりに，系層がボビンの芯筒を圧縮する荷 重（以後芯筒圧縮荷重）またはボビンのつばを押し 広げようとする荷重（以後つば圧縮荷重）を測定す るためのモデルボビンを取り付け，ボビン状の巻系 体形成をしながら上記荷重の測定ができるモデルワ インダである．給糸パーン(1)から解じょされた糸は テンサ(2)に入る.テンサにより $T$ が $2 \mathrm{kgf} / \mathrm{mm}^{2}$ (19.6MPa) となるようにテンサ重りを調節する.

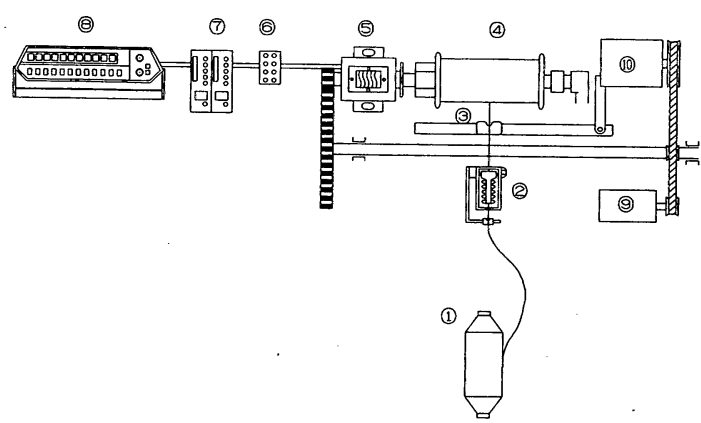

(1)Pirn (2Tensor (3)Yarn Guide (4)Yarn Package (5) 1 ip Ring (aBridge Box (OStrain Amplifier (BDigital Voltmeter (9Motor (10Traverse System

Fig. 2 Schematic illustration of the experimental apparatus

その後, 糸はトラバース装置(10により綾振りを受け ながら，モデルボビン(4)上へ巻かれていく。ボビン の回転数は 2,000 rpm とする. 芯筒圧縮荷重測定用 モデルボビンの概略を図 3 に示す.アルミ合金製の 芯筒は上下二つの部分に分割されており，それぞれ の部分は軟鋼製の薄板（以後ステイ）により結合さ れているため，芯筒圧縮荷重によってステイ部だけ が変形しやすくなっている，ステイには図中にハッ 


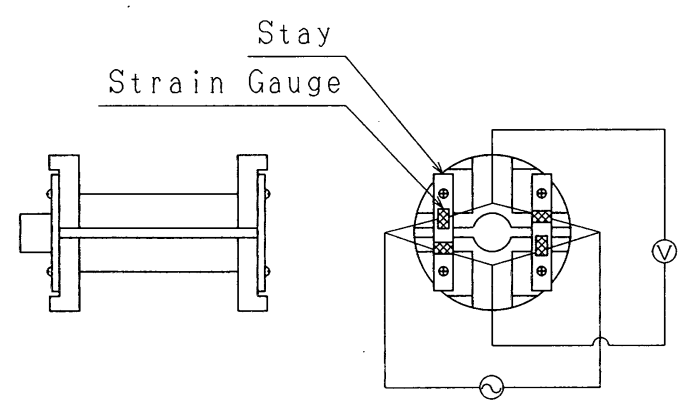

Fig. 3 Bobbin to measure the radial load compressing its barrel

チングで示すようにひずみゲージが貼り付けてあ り，4枚のゲージによってブリッジを形成している. これょり出力されるひずみから芯筒圧縮荷重を算出 する.つば圧縮荷重測定用モデルボビンの概略を図 4 に示す. このボビンの片側のつばはボビンのバレ ルとは分離されており，外側から固定されている 2 本のステイによって支えられているため, つば圧縮 荷重によってステイ部だけが変形しやすくなってい る. ステイに貼られたひずみゲージから出力される ひずみより，2 ゲージ法によってつば圧縮荷重を算 出する．モデルボビンのひずみゲージから検出され た荷重の信号はスリップリング(5)，ブリッジボック ス (6) (図 3 の 4 ゲージ法の場合であ(7)への接続のた めに(6)を用いる), 動ひずみ計(7)を介してデジタル 電圧計(8)に出力される.

ボビン上に巻き付ける系は, 表 1 に示したポリエ ステルフィラメント系およびナイロンフィラメント 糸のそれぞれ原糸と撚糸, 計 4 種類のヤング率の異 なる糸である.これらの糸をモデルボビン上に巻き 取っていった場合, ボビン回転数と巻き取り張力は 一定であるので, 巻き取り開始からの経過時間と巻

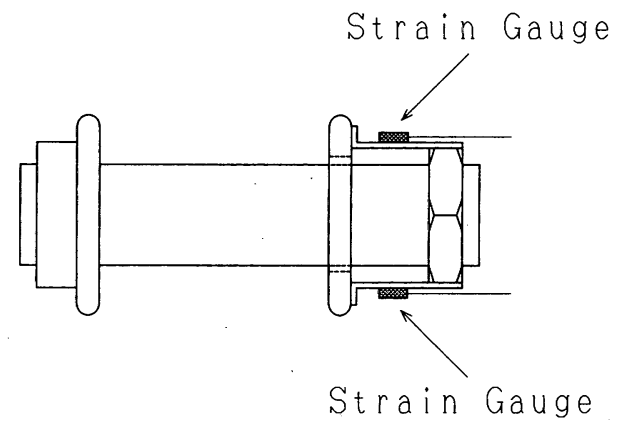

Fig. 4 Bobbin to measure the axial load expanding its flanges
系体直径との関係をあらかじめ求めておき, ある時 間におけるデジタル電圧計8の出力を読み取れば, それに対応する糸層厚さ $\Delta r$ における芯筒圧縮荷重 またはつば圧縮荷重を求めることができる，測定は $\Delta r$ が $15 \mathrm{~mm}$ になるまで行った.

\section{3 測定結果之考察}

芯筒圧縮荷重をモデルボビンの円筒部分の表面積 で除すことによって半径方向圧縮応力が算出でき る. 系層厚さ $\Delta r$ の増加に伴う半径方向圧縮応力 $\sigma_{r}$ の变化を図 5 に示す.この測定值は各試料系におい て 3〜5 回測定したときの平均値である. 糸のヤン グ率が小さいほど半径方向圧縮応力が大きく, その 増加割合む大きくなっている.このことは以下の原 因によると考えられる. すなわち，本研究では巻系 体の単位面積当たりの張力を一定として巻き取りを 行っているため, ヤング率が小さい系ほど糸に大き なひずみを与えながら系層を形成していることにな る. また図 1 で示したような外側への系の累積に伴 う内側の系層のひずみの減少が各系に対して同程度 生じているとすると，このひずみの減少による応力 の減少はヤング率の小さな糸の方が小さくなる（す なわち大きな応力となる).

つば圧縮荷重をそのときのつばに接している糸層 の面積で除すことによって平均つば圧縮応力が算出 できる. 糸層厚さ $\Delta r$ の増加に伴う平均つば圧縮応 力 $\sigma_{\mathrm{zAVE}}$ の変化を図 6 に示す. 糸のヤング率が小さ いほど平均つば圧縮応力は大きくなっている.これ は図 5 の場合と同じ理由によると考えられる. ま た, つばに接している糸層の面積は糸層厚さに対し て 2 次曲線的に増加していくので, 実際のつば圧縮 荷重む糸層厚さに対して 2 次曲線的に増加していく

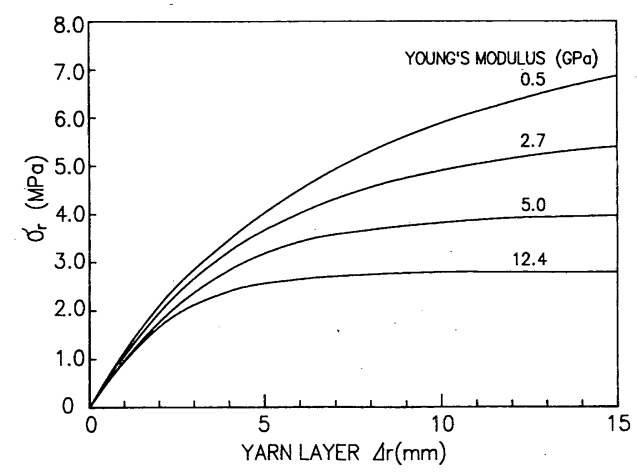

Fig. 5 Relation between the radial compressive stress $\sigma_{r}$ and the cumulated yarn layer $\Delta r$ 


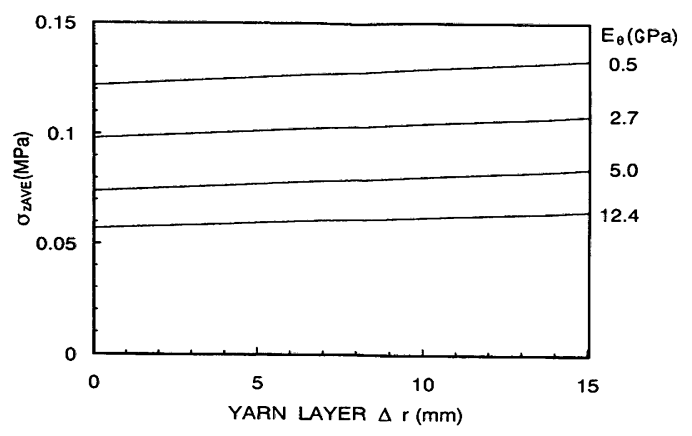

Fig. 6 Relation between the average axial compressive stress $\sigma_{z \mathrm{AVE}}$ and the cumulated yarn layer $\Delta r$

\section{ことに注意を要する.}

しかし図 5 と図 6 の縦軸を比べると，どの糸種に おいてあ $\sigma_{\mathrm{zAVE}}$ よりは $\sigma_{r}$ の方がはるかに大きいの で, (図 3 および図 4 のモデルボビンの概略の寸法 は後述の図 8 とほぼ同じ）巻糸体はボビンのつばよ りは芯筒を強く圧縮することが分かる。

\section{3. ボビン変形の有限要素法による解 析}

\section{1 基礎方程式 $^{\text {(7) }}$}

本解析では，対象が回転体であるためボビンの自 軸を中心軸にとった円筒座標系を用い，ボビンに対 し荷重が軸対称にかかっているため 2 次元的な形で 解析を行う。

座標系は図 7 のような円筒座標系 $(r-\theta-z)$ を用 いる. 各方向の直ひずみ, 直応力をそれぞれ, $\varepsilon_{r}, \varepsilon_{\theta}$, $\varepsilon_{z}, \sigma_{r} ; \sigma_{\theta}, \sigma_{z}, r-\theta, \theta-z, r-z$ 面内のせん断ひずみ, せん断応力をそれぞれ $\gamma_{r \theta}, \gamma_{z \theta}, \gamma_{r n}, \tau_{r \theta}, \tau_{z \theta}, \tau_{r z}$ 之定義 する. $r$ 方向の変位を $u, z$ 方向の変位を $w$ で表すと

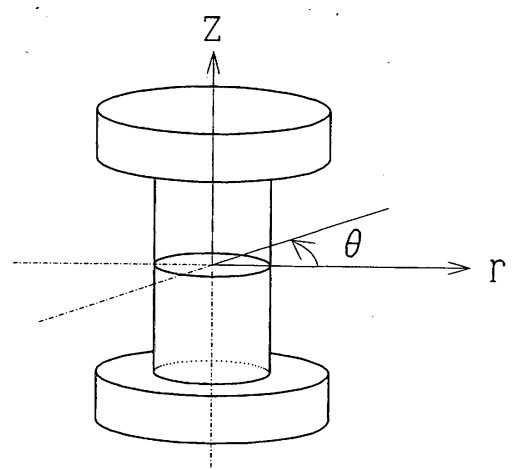

Fig. 7 Coordinate system for the bobbin
し, 軸対称な変形しか生じないので変位の $\theta$ 方向成 分は 0 となる．考慮すべきひずみと変位の関係は次 の(4)式となる:

$$
\begin{aligned}
& \varepsilon_{r}=\frac{\partial u}{\partial r} \\
& \varepsilon_{\theta}=\frac{u}{r} \\
& \varepsilon_{z}=\frac{\partial w}{\partial z} \\
& \gamma_{r z}=\frac{\partial u}{\partial z}+\frac{\partial w}{\partial r} .
\end{aligned}
$$

応力とひずみの関係は, 次のようになる.

$$
\left[\begin{array}{l}
\sigma_{r} \\
\sigma_{\theta} \\
\sigma_{z} \\
\tau_{r z}
\end{array}\right]=\left[\begin{array}{cccc}
d_{1} & d_{2} & d_{2} & 0 \\
d_{2} & d_{1} & d_{2} & 0 \\
d_{2} & d_{2} & d_{1} & 0 \\
0 & 0 & 0 & G
\end{array}\right]\left[\begin{array}{l}
\varepsilon_{r} \\
\varepsilon_{\theta} \\
\varepsilon_{z} \\
\gamma_{r z}
\end{array}\right]
$$

なお, $d_{1}, d_{2}, G$ は

$$
\begin{aligned}
d_{1} & =\frac{E(1-\nu)}{(1+\nu)(1-2 \nu)} \\
d_{2} & =\frac{E \nu}{(1+\nu)(1-2 \nu)} \\
G & =\frac{E}{2(1+\nu)}
\end{aligned}
$$

である.ここで $E$ はヤング率, $\nu$ はポアソン比であ る. 力のつり合い方程式は次のようになる.

$$
\begin{aligned}
& \frac{\partial \sigma_{r}}{\partial r}+\frac{\partial \tau_{\pi z}}{\partial z}+\frac{\sigma_{r}-\sigma_{\theta}}{r}+f_{r}=0 \\
& \frac{\partial \sigma_{z}}{\partial z}+\frac{\partial \tau_{r z}}{\partial r}+\frac{\tau_{r z}}{r}+f_{z}=0
\end{aligned}
$$

ただし $f_{r}, f_{z}$ はそれぞれの方向の荷重密度（体積力） である．境界条件は以下のようになる。

対称軸上において $u=0$

固定端において $\quad u=0, w=0$

自由において $\quad\left[\begin{array}{ll}\sigma_{r} & \tau_{n} \\ \tau_{r z} & \sigma_{z}\end{array}\right]\left[\begin{array}{l}n_{r} \\ n_{z}\end{array}\right]=\left[\begin{array}{l}0 \\ 0\end{array}\right]$

ただし， $n_{r}, n_{z}$ は法線の方向余弦である.

これらの基礎方程式をもとに有限要素による解析 を行う。

\section{2 解析モデルとメッシュデータ}

本解析に用いたボビンの寸法を図 8 に示す. 今回 モデルとしたボビンは，上下左右対称であるため全 体の $1 / 4$ について解析を行う。材料にはフェノール パルプチップを想定して，ヤング率は $6.9 \mathrm{GPa}$ ， ポ アソン比 0.33 とする. 図 9 にメッシュデータを示 す.ボビンに $\Delta r=13.5 \mathrm{~mm}$ となるまで糸を巻き付 けた状態を巻系体形成終了時とし，このときの変形 


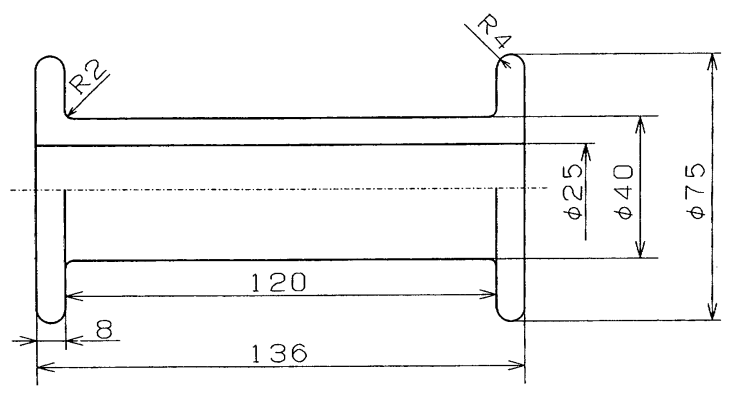

Fig. 8 Dimensions of the analyzed bobbin

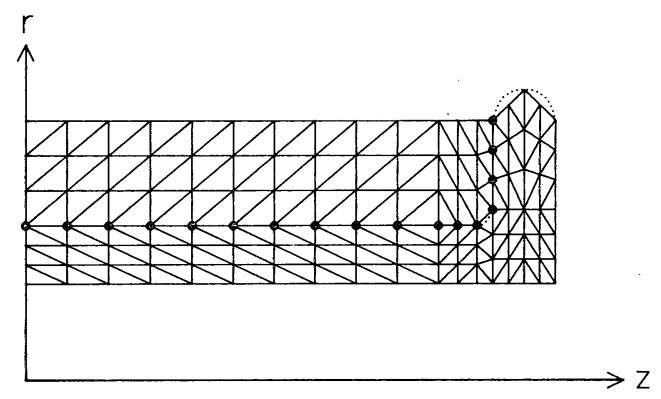

Fig. 9 Mesh data of the analyzed model

状態について解析する.メッシュは接点数が 126 接 点, 要素数が204要素からなり,つばのつけ根付近に ついては細かい分割を行った。図中のの印は荷重条 件を与える接点であり，このの印を結んだラインよ り左上部が糸層の部分であり右上部または下部がボ ビンである.

\section{3 荷重条件}

本解析において，境界条件として与える $r$ 方向お よび $z$ 方向の応力は, より実際的な結果を得るため 芯筒圧縮荷重およびつば圧縮荷重の測定結果をもと に算出する.

ここで, 巻糸体がボビンの芯筒を圧縮する応力 は, 芯筒表面上の各位置において一定であると考え られるため, 境界条件として与える $r$ 方向の応力は 図 5 における $\Delta r=13.5 \mathrm{~mm}$ のときの $\sigma_{r}$ の值を用い

る. 図 10 に糸のヤング率の違いによる巻糸体形成 終了時の半径方向圧縮応力の変化を示す.

一方， $\sigma_{z}$ としては図 6 に示した単純な平均値では なく, $r$ 方向での分布を考慮して以下のように求め た. 半径 $r$ から最外層半径 $R_{0}$ までの糸層がボビン のつばを圧縮する応力 $\sigma_{z}{ }^{*}\left(r, R_{0}\right)$ は, 先に報告した 巻系体内部応力理論 ${ }^{13)}$ より, 次のようになる

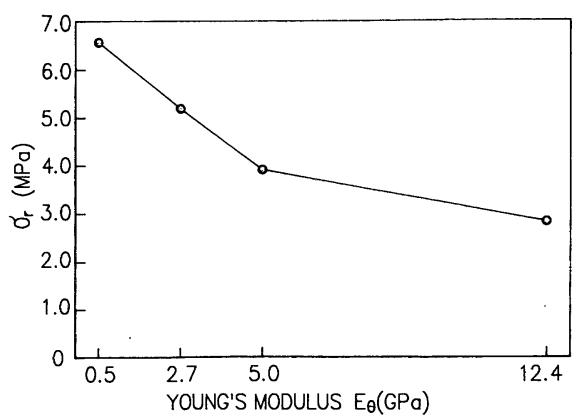

Fig. 10 The compressive stress in radial direction when yarn package completed

$$
\begin{aligned}
& \sigma_{r}^{*}\left(r, \quad R_{0}\right)=-T\left\{\left(\nu_{3}+\alpha \nu_{1}\right) r^{\alpha-1}\right. \\
& \left.\quad+\beta r_{0}\left(\nu_{3}-\alpha \nu_{1}\right) r^{-\alpha-1}\right\} I\left(r, R_{0}\right)
\end{aligned} \quad \begin{aligned}
I\left(r, R_{0}\right)=\int_{r}^{R_{0}} \frac{d R}{R^{\alpha}+\beta r_{0}^{2 \alpha} R^{-\alpha}} \\
\alpha^{2}=\frac{1-\nu_{3}^{2}}{\omega-\nu_{1}^{2}} \\
\beta=\frac{-\nu_{1} \omega_{0}\left(1+\nu_{3}\right)+\alpha\left(1-\omega_{0} \nu_{1}^{2}\right)}{\nu_{1} \omega_{0}\left(1+\nu_{3}\right)+\alpha\left(1-\omega_{0} \nu_{1}^{2}\right)} \\
\omega_{0}=\frac{E_{\theta}}{E_{r}}\left(=\frac{1}{\omega}\right)
\end{aligned}
$$

ただし $T$ は単位断面積当たりの巻張力, $\omega$ は半径方 向ヤング率 $E_{r}$ の円周方向ヤング率 $E_{\theta}$ に対する比, $\nu_{1}, \nu_{3}$ はそれぞれ $r$ または $z$ 方向のひずみに対する $\theta$ 方向のポアソン比および $r$ または $z$ 方向のひずみ に対する $z$ または $r$ 方向のポアソン比を示す. 式(15) において， $E_{\theta}$ としては前報备の結果より，ボビン上 に巻かれた糸のヤング率（表 1 に示した各糸のヤン グ率) を用いる. 次に $\omega$ をパラメータとして変化さ せ, 得られた $\sigma_{z}$ から算出した巻系体形成終了時のつ ば圧縮荷重が測定結果と一致したときの $E_{r}$ を巻系 体の半径方向ヤング率として用いた。ここで, ポア ソン比は $\nu_{1}=\nu_{3}=0.4$ と一定に, また $E_{r}=E_{z}$ として いる. 図 11 に各試料系での実験結果をあとにした

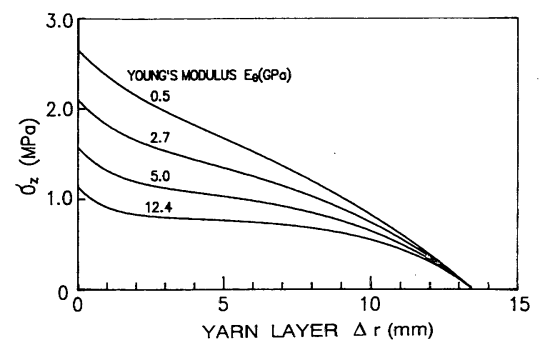

Fig. 11 Distribution of the flange's compressive stress when yarn package completed 


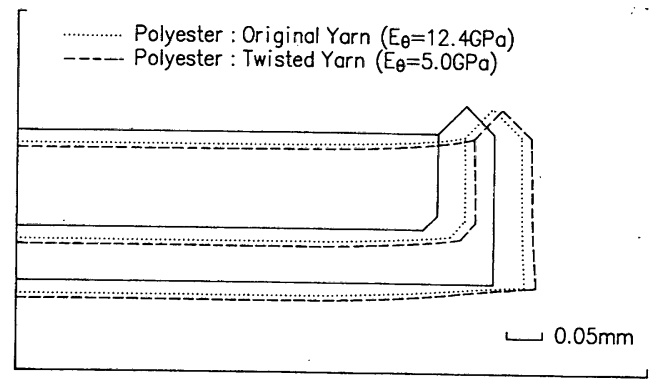

Fig. 12 Chart of the bobbin deformed (Polyester)

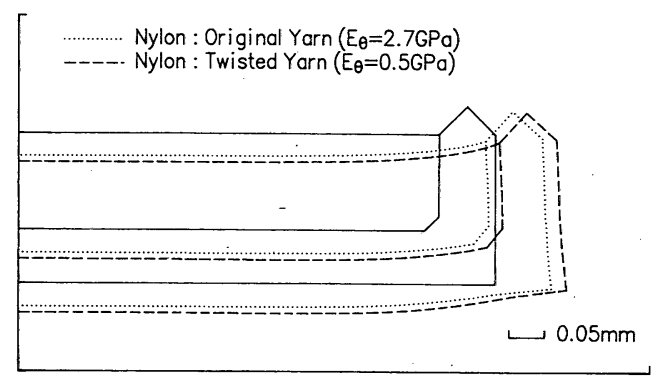

Fig. 13 Chart of the bobbin deformed (Nylon) つば圧縮応力分布 (巻糸体内部の応力 $\sigma_{z}$ の分布) の 計算結果を示す.これより境界条件として与える $z$ 方向の応力を求める.

\section{4 解析結果および考察}

図12および図13にヤング率の異なる糸を用いて巻 糸体を形成した際のボビンの変形の様子を有限要素 法により解析した結果を示す．糸のヤング率が小さ いほどボビンの変形は大きくなる，この図より，っ ばのつけ根の外側の位置での変位が最む大きくなっ ている.これは $z$ 方向の荷重がつばのつけ根の位置 で最も大きいためと考えられる，また，つばは相対 的に内側に傾くような形で変形していることが分か る.これはボビンの芯筒を圧縮する $r$ 軸方向の荷重 がつばを圧縮する $z$ 軸方向の荷重に比べかなり大き いことによるものと思われる．この現象は糸のヤン グ率が小さくボビンに加わる荷重が大きくなるほど 顕著になる。

これらの結果，ボビンの設計を行うとき，芯筒と つばの接点付近に応力が集中しないよう考慮しなけ ればならないことが分かる。

\section{4. 結 言}

本研究では, ヤング率の異なる糸を用いてつば付 ボビン上に巻糸体を形成することにより，系のひず
みの違いによってボビンに加わる力がかなり変わっ てくることが分かった. また, 巻系体内部応力によ るつば付ボビンの変形についてモデル実験を通して 明らかにした。

その結果, 以下の結論を得た。

(1)系層がつば付ボビンの芯筒を圧縮する荷重は糸 のヤング率が小さいほど大きく, その荷重増加 の割合は糸層の増加に伴い小さくなる.

(2)系層がボビンのつばを圧縮する荷重は糸のヤン グ率が小さいほど大きく, その荷重増加の割合 は糸層の増加に伴い大きくなる。

(3)巻糸体はボビンのつばよりも芯筒を強く圧縮す る.

(4)巻糸体内部応力によるつば付ボビンの変形は, 糸のヤング率が小さいほど大きく，つばのつけ 根付近での変位が最む大きくなる.

なお,この研究成果の一部は平成 3 年日本繊維機 械学会北陸支部研究発表会および平成 4 年日本繊維 機械学会北陸支部研究発表会において発表した。最 後に本研究を遂行するに当たり, 太平株式会社岡本 正氏に多大なる協力を頂いた。 また本研究室の卒業 生である近藤寿彦氏，伴場秀樹氏，谷義則氏には実 験やプログラム作成においてご協力を頂いた。ここ に記して感謝の意を表する。

\section{文献}

1）西原利夫, 藤野清久, 平井恒夫, 津久間新; 機論, 26,588 (1960)

2）中島達夫；絨機誌，20，T194（1967）

3）中島達夫, 太田計正, 高木久弥; 織機誌, 20, T226 (1967)

4）大沢源一郎，小山敏夫；綫学誌，33，T423 (1977)

5）新宅救徳，山本孝，土定育英，喜成年泰；織学誌，44，353 (1988)

6) B. G. Neal ; J. Strain Analy., 2, 213 (1967)

7) B. Beddoe ; J. Strain Analy., 2, 207 (1967)

8) V. Vicentini ; J. Strain Analy., 4, 48 (1969)

9) P. Ursiny ; Textiletechnik ; 36,535 (1986)

10) M. G. Catlow, G. W. Walls; Shirley Inst. Mem., 35, T410 (1962)

11) S. K. Batra, D. S. Lee, S. Backer ; Text. Res. J., 46, 453 (1976)

12) S. K. Batra, D. S. Les, S. Backer ; Trans. ASME, Series B, 100, FEB, 8 (1978)

13）新宅救徳, 尾田十八, 奥野登起男; 瀻学誌, 45, 278 (1989)

14）新宅救德，尾田十八，奥野登起男; 繊学誌, 46, 115 (1990)

15）新宅救徳，尾田十八，谷義則，奥野登起男; 䋞機誌，43, T86 (1990)

16）新宅救徳，尾田十八，谷義則，奥野登起男；織機誌，43, T105 (1990)

17）戸川隼人；“有限要素法概論”，p. 219 , 培風館 (1981) 